\title{
Warm Springs Ran Deep: Friends-and-Neighbors Voting in the U.S. Presidential Elections of 1940 and 1944
}

\author{
Franklin G. Mixon, Jr. ${ }^{1}$ \\ ${ }^{1}$ Center for Economic Education, Columbus State University, Columbus, GA, USA \\ Correspondence: Franklin G. Mixon, Jr., Center for Economic Education, D. Abbott Turner College of Business, \\ Columbus State University, 4225 University Avenue, Columbus, GA, 31907, USA. Tel: 1-706-507-8052. \\ E-mail: mixon_franklin@columbusstate.edu
}

Received: March 6, 2013 Accepted: March 20, 2013 Online Published: May 30, 2013

doi:10.5539/jpl.v6n2p105 URL: http://dx.doi.org/10.5539/jpl.v6n2p105

\begin{abstract}
The present study extends recent research on friends-and-neighbors voting in presidential elections by examining a unique situation occurring during the presidential elections of 1940 and 1944, both of which were won by incumbent President Franklin D. Roosevelt. What makes these elections unique is that Roosevelt, who grew up in Hyde Park, New York, contracted polio in 1921, and thereafter spent a large portion of his life in Warm Springs, Georgia, seeking the physical comfort provided by the magnesium-rich, warm-water pools. By the time these elections occurred, many Georgia citizens in and around Meriwether County, wherein Warm Springs is situated, viewed Roosevelt as one of their own. Statistical results from the 1940 and 1944 general elections presented in this study indicate that the home-area effect favoring Roosevelt in Meriwether and contiguous counties averaged a solid 7.8 percentage points across the two presidential elections. This result is even more striking when compared to the smaller home-area effect found for the Duchess County area of New York, which includes Roosevelt's boyhood home of Hyde Park.
\end{abstract}

Keywords: friends-and-neighbors voting, localism in voting, agency costs in representative government

"To a generation of west Georgians, [Franklin D. Roosevelt] was both the president and a trusted friend who could be seen waving as he passed by in his convertible or rode by in a train on his way to the nation's capital . . . He quickly grew to love Georgia and its people, and they welcomed him as their adopted son."

(Editors, 2009)

"To a Georgian far from home there was a sudden and bitter nostalgia for home at the news of the President's passing in Warm Springs. I could see the dogwood in bloom and the green of the trees. I knew that the peach blossoms were out and that the warm Georgia sun had been like a benediction to the tired body of the ailing president. And I wanted to be home with my own fellow Georgians as they mourned him ..."

(Ralph McGill, 1945)

"The train pulled out from Warm Springs around 9:05 a.m. The windows on the train car holding Roosevelt's coffin were left open, and the coffin was easily visible. Thousands of people gathered along the tracks as the train made its way through south and central Georgia to Atlanta. Eleanor was surprised at the response of the people; she had never been an active participant in Roosevelt's Warm Springs ventures, and rarely stayed long on her visits there. But now she was deeply moved as she witnessed just how strongly the people of Georgia ... loved him."

(USG, 2012)

\section{Introduction}

As in the provision of other goods and services, political representation, either through direct democracy or representative government, is not costless. Depending on the constitutional framework within which it operates, an electorate will incur varying levels of decision-making and agency costs when establishing a democratic system of government. In opting for representative democracy, an electorate is able to reduce the higher decision-making costs of direct democracy, which are those costs associated with gathering information on individual issues and voting on various referenda related to those issues. However, the reduction in 
decision-making costs is usually accompanied by an increase in agency costs. As Sass (1992: 407) indicates, agency costs - those that consist of expenditures meant to monitor and constrain representatives' (utility-maximizing) behavior plus the net costs to the electorate of undesired representatives' actions that remain - can be substantial, particularly when the preferences of the electorate and those of their representative diverge substantially. (Note 1)

Borrowing from Faith and Tollison's (1983) managerial hierarchies analogy (to elections), Kjar and Laband (2002) explain that the friend-and-neighbors (localism) voting phenomenon, wherein an electorate supports a local candidate who has lived in the political jurisdiction for many years, serves as a means of reducing the expected agency costs of representative government. They argue that the advantages of selecting a home-grown candidate come through (1) the home candidate's human capital advantage of knowing how the local community works, (2) the lower costs facing the electorate that is associated with detecting the merits of the local candidate, and (3) the greater human capital that local candidates risk, as a Klein and Leffler (1981) type of performance bond, relative to their far-away opponents with little or no connection to the local community or electorate (Kjar \& Laband, 2002: 143-144). As Kjar and Laband (2002: 144) add,

Voters understand and appreciate the implied efficiency of casting their ballots in favor of someone who has a lot to lose locally from nonperformance as their (legislative) representative.

The present study extends recent research on friends-and-neighbors voting in presidential elections by examining a unique situation occurring during the first two presidential elections of the 1940s. Both of these were won by incumbent President Franklin D. Roosevelt, who first took office in the White House in 1933 after winning the presidential election of 1932. Having also won re-election in 1936 for a second term from 1937 to 1941, Roosevelt secured his third and fourth consecutive terms, respectively, with victories in 1940 and 1944. What makes these elections unique is that Roosevelt, who grew up in Hyde Park, New York, contracted polio in 1921, and thereafter spent a large portion of his life in Warm Springs, Georgia. He first travelled to rural Georgia in 1924 in search of comfort and rehabilitation that was reportedly provided by the warm mineral springs that fed swimming pools at a resort in Warm Springs. By the time the elections in 1940 and 1944 occurred, many Georgia citizens in and around Meriwether County, wherein Warm Springs is situated, viewed Roosevelt as one of their own. In many ways, the sentiment was mutual. Thus, general election returns in Georgia, for both the 1940 and 1944 presidential elections, offer a unique avenue for exploring the effect of friends-and-neighbors voting (localism) in U.S. presidential elections.

\section{Literature Review}

One of the first studies to examine localism in elections was conducted by Lewis-Beck and Rice (1983). They examined major-party voting shares across U.S. presidential elections from 1884 to 1980 using the equation,

$$
H=\left(S_{a}-S_{e}\right)-\left(N_{a}-N_{e}\right)
$$

wherein $H$ is the home state advantage (in terms of percentage points of the state's popular vote), $S_{a}$ is the presidential candidate's actual popular vote percentage in his home state, $S_{e}$ is the average popular vote percentage for the candidate's party in his home state over the previous five presidential elections, $N_{a}$ is the presidential candidate's actual national popular vote percentage, and $N_{e}$ is the average national popular vote percentage for the candidate's party over the previous five presidential elections (Lewis-Beck and Rice, 1983: 550). (Note 2) Lewis-Beck and Rice found that $H$ averaged four percentage points across U.S. presidential elections (1884-1980).

Over the past 10 years, a few studies in the economics literature have addressed the friends-and-neighbors voting phenomenon in national elections that was examined 30 years ago by Lewis-Beck and Rice (1983). These include Kjar and Laband (2002), which employs precinct-level vote shares data from the 1998 election in Alabama's $3^{\text {rd }}$ Congressional District. County-level results for the race between the Democrat and Republican in this particular case suggest that the home-county effect ranges from a low of 8.18 percentage points to a high of 12.35 percentage points, depending on empirical specification. As such, Kjar and Laband's (2002) results support the "performance bond" view of friends-and-neighbors voting as a way of mitigating the agency costs of representative government.

Other studies have employed the regression-based approach in Kjar and Laband (2002), including Mixon and Tyrone (2004) and Mixon, King and Lawing (2008). These studies examine presidential elections from 1972-2000 and 1972-2004, respectively, finding that the home-state effect in presidential elections is 5.19 percentage points and 4.88-5.52 percentage points, respectively. The value at the low end of this range is quite 
similar to the effect of four percentage points found about 25 years earlier by Lewis-Beck and Rice (1983). Lastly, Kahane's (2009) more recent study is the first to include macroeconomic conditions in an empirical analysis of friends-and-neighbors voting. (Note 3) In doing so, he finds that the home-state effect in presidential elections from 1972-2004 is 2.96 percentage points, a figure that places Lewis-Beck and Rice's estimate at about the center of a range that runs from 2.96 percentage points (Kahane, 2009) to 5.19 percentage points (Mixon \& Tyrone, 2004).

Studies on the home-state effect such as those detailed above are supported by research examining other areas of politics. For example, Aspin and Hall (1989) find support for friends-and-neighbors voting in judicial elections, while Devine and Kopko (2011) find support for friends-and-neighbors voting for vice presidential candidacies. Support also extends to studies of elections occurring outside of the United States (Malcová, 2012), and to those using Geographical Information System (GIS) data to find nonlinearities in the home-state phenomenon (Gimpel, Karnes, McTague and Pearson-Merkowitz, 2008). All of the studies noted above frame the hypothesis that is tested in this study. Before turning to the empirical tests, section 3 offers a brief history of Roosevelt's visits to Warm Springs, Georgia.

\section{A Brief Look at Roosevelt's History in Warm Springs, Georgia}

Franklin Delano Roosevelt contracted polio (i.e., poliomyelitis), or what was then commonly referred to as infantile paralysis, in August of 1921 while on a family vacation on Campobello Island in Canada (Editors, 2009). A short while later, Roosevelt learned from George Peabody, a prominent businessman from Roosevelt's home state of New York, about a young polio victim's recovery from the disease after spending time in the warm springs-fed pools at Peabody's Meriwether Inn, which was located near the town of Warm Springs in west central Georgia's Meriwether County (Editor, 1924; NPS, 2012; USG, 2012). (Note 4) The primary benefit of the warm springs, which emanated from Pine Mountain, came from their year-round temperature of 88 (90) degrees, which allowed Roosevelt, and others who suffered from polio, to remain in the water for lengthy periods of time, unlike pools filled with colder water. (Note 5) A secondary benefit came from the water's magnesium content, which provided greater buoyancy to the bathers who sought hydrotherapy as a treatment for the disease (Editor, 1924; USG, 2012).

Roosevelt made his first visit to the Warm Springs area in October of 1924. He stayed there for about two and one-half weeks, bathing and exercising in the warm-water pools (Stevens, 1947; USG, 2012). During this period, he wrote to his wife, Eleanor, that his legs had improved from general exercise in the pools, and that he had even worked out some specialized hydrotherapies (Roosevelt, 1950; USG, 2012). That first visit to Warm Springs attracted a reporter from the Atlanta Journal, who penned an article about Roosevelt's warms springs therapy, stating that Roosevelt had decided to return to the area the following April (of 1925) for two months of additional therapy, and to begin construction of a cottage in the Pine Mountain hills (Editor, 1924; USG, 2012).

Roosevelt did return to Warm Springs on 1 April 1925, and remained there through 15 May 1925. By then, news of his 1924 trip there had spread across the United States by way of national syndication of the Atlanta Journal article, attracting a number of polio victims to seek relief in the warm waters. Roosevelt welcomed the new visitors, and soon took over management of their hydrotherapies (Lippman, 1977; USG, 2012). (Note 6) It was also during this second visit that Roosevelt, in conjunction with Peabody and others, began making plans to improve Warm Springs by adding new buildings and roads, so that it may become a haven for other polio victims.

Roosevelt ultimately purchased the Meriwether Inn from Peabody in April of 1926, including all of the cottages, 1,200 acres of land, and the warm springs (Roosevelt, 1950; Lippman, 1977; USG, 2012). From January of 1924 until he became President of the United States in March of 1933, Roosevelt would make 25 separate visits to Warm Springs in order to rest and recuperate in the warm, therapeutic springs. Included among these were lengthy visits while serving as Governor of New York, and a four-week visit during the spring of 1932 while running for the U.S. presidency (USG, 2012). (Note 7) He even managed to fit in a two-day visit to Warm Springs on 23 October 1932, just two weeks before the 1932 presidential election, at which time he was greeted enthusiastically by a crowd of more than 10,000 people (Lippman, 1977; USG, 2012). After securing victory in the presidential election of 1932, Roosevelt returned to his "Little White House" - the name given to his cottage in the Pine Mountain hills - near Warm Springs in November/December of that year for a two-week rest and recuperation (Roosevelt, 1950; USG, 2012). (Note 8)

The extent to which Roosevelt visited Warm Springs is described in Figure 1, which covers the entire period of 1924 to 1945 . Beginning in 1925 and running through 1932, Roosevelt spent approximately 10 percent to 50 percent of each year in Warm Springs. With the exception of 1942, he visited the area at least once each year for 
the entire period from 1924 to 1945 (USG, 2012). Even after assuming the presidency in 1933, Roosevelt continued to spend significant amounts of time at the Little White House near Warm Springs. During each of the years 1933, 1934 and 1935, Roosevelt spent between five and 10 percent of his time near Warm Springs. It was during this period that he was formulating some of his New Deal ideas, such as the Rural Electrification Administration (REA) and the Agricultural Adjustment Act, that historians credit to his visits with the farmers and others living in Meriwether and the surrounding counties of west-central Georgia (NPS, 2012; USG, 2012). (Note 9)

Roosevelt's travels throughout west Georgia, where he became the area's "adopted son" (see epigraph above), are well documented. For example, while visiting Warm Springs in January and February of 1928, Roosevelt travelled to Americus, Georgia, located to the southeast in Sumter County, to speak to the Chamber of Commerce (USG, 2012). He was also invited to give a speech on 2 October 1928 in Manchester, Georgia, just a few miles east of Warm Springs in Meriwether County. (Note 10) It was on this particular occasion that he allowed his name to be submitted to the New York Democratic Convention as a candidate for governor, where he won election as New York's governor the following month (Editors, 2009). Later, during his campaign for the presidency in 1932, he delivered the commencement address at Oglethorpe University in Atlanta (Hudson, 1994; Editors, 2009), while in 1938 he travelled to Barnesville, Georgia, which is just east of Warm Springs in Lamar County, to deliver a commencement address at Gordon College (Editors, 2009). (Note 11) Roosevelt also visited Columbus, Georgia, which is located in Muscogee County, just to the southwest of Warm Springs and is home to Fort Benning, on a few occasions (USG, 2012). (Note 12)

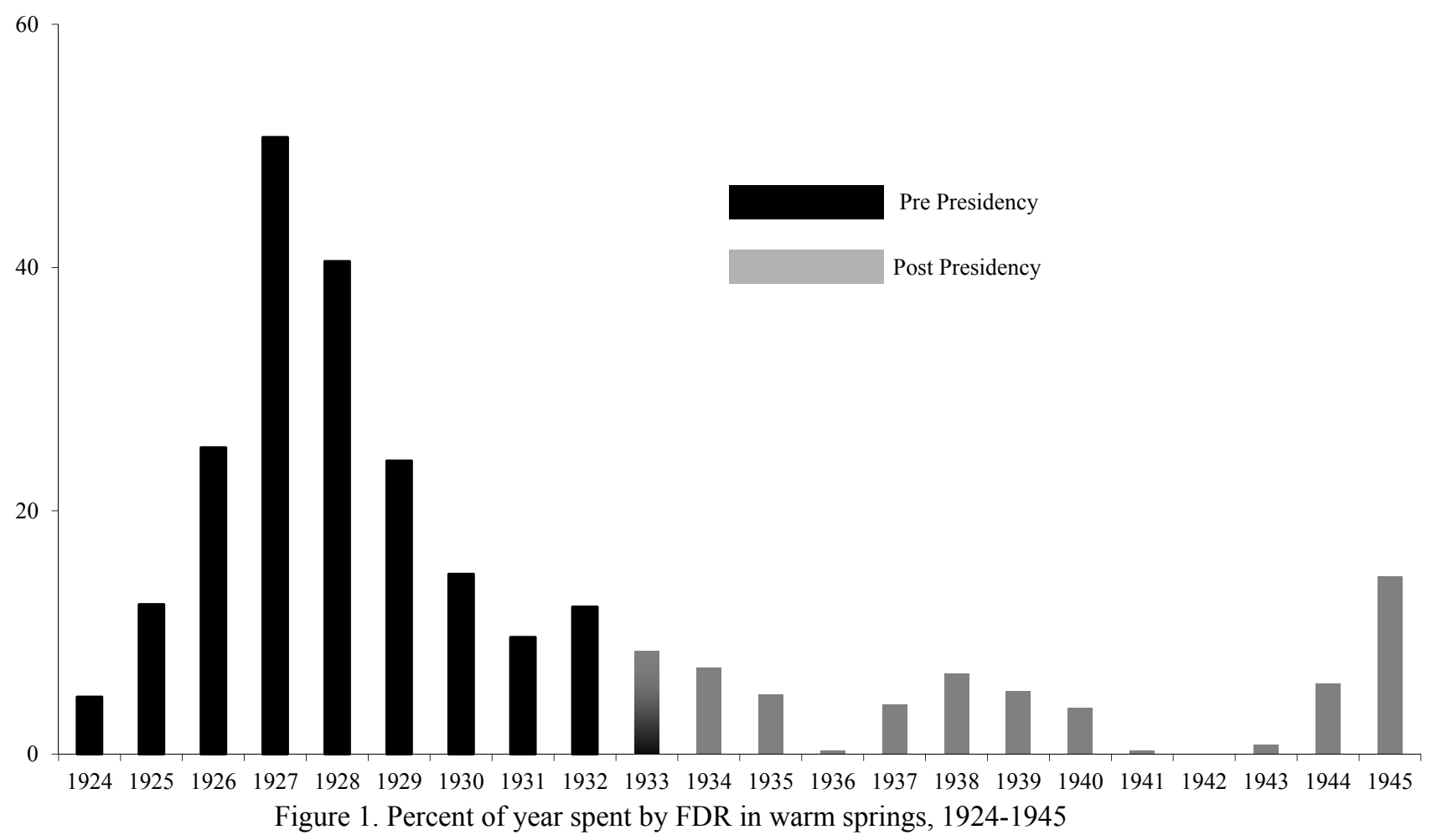

Note: The percent for 1945 covers the period from 1 January through Roosevelt's death on 12 April.

Perhaps the best indicator of the value to Roosevelt of west-central Georgia is what is known as the Meriwether-Pike Scenic Biway, a 55-mile road route connecting several of Roosevelt's favorite locales. The Biway connects Warm Springs, near Roosevelt's Little White House, with the towns of Woodbury (Meriwether County), Gay (Meriwether County), Molena (Pike County) and Manchester (Meriwether County). Just off of the Biway are other towns frequented by Roosevelt, such as Greenville (Meriwether County) and Concord (Pike County). Also included along the route are Dowdell's Knob, a plateau offering a scenic view of the Pine Mountain hills, and where Roosevelt would often host picnics, and Flat Shoals, a favorite fishing spot of Roosevelt and his companions (Winn, 1996). (Note 13) 
Lastly, evidence of the importance of Warm Springs to Roosevelt was his practice of conducting official national business while convalescing at the Little White House. Dignitaries who visited Roosevelt there to discuss government matters included various southern governors, such as Georgia Governor Eurith Rivers, who visited in 1938. National and international dignitaries also travelled to Warm Springs to meet with Roosevelt. Examples of these are U.S. Secretary of the Treasury Henry Morgenthau, and Philippine President Sergio Osmena, who travelled to Georgia in 1945 in order to discuss post-war national independence for the Philippines (NPS, 2012; USG, 2012). Given the brief account of Roosevelt's history in west central Georgia provided above, the U.S. Presidential elections of 1940 and 1944, both of which Roosevelt won, offer a unique and potentially compelling testing ground of the friends-and-neighbors voting hypothesis from public choice economics. These tests are covered in the next section of the study.

\section{A Statistical Analysis of Localism in the 1940 and 1944 Elections}

Following the approach in Lewis-Beck and Rice (1983) and in more recent studies in the same genre (e.g., Kjar \& Laband, 2002; Disarro, Barber \& Rice, 2007), two statistical tests, one involving separate cross-sections of all Georgia counties for each of the 1940 and 1944 presidential elections, and another employing panel data for all counties and over both elections, are developed here to test the friends-and-neighbors voting hypothesis. (Note 14) These two models, presented below in equations (2) and (3), respectively, both regress countywide vote shares (VOTESHARE) on the dummy variable HOME, which is equal to 1 for Meriwether and contiguous counties, and 0 otherwise.

$$
\begin{gathered}
\text { VOTESHARE }=\alpha+\beta_{1} H O M E+\beta_{2} L G C A P+\varepsilon_{1} \\
\text { VOTESHARE }=\gamma+\delta_{1} H O M E+\delta_{2} L G C A P+\delta_{3} Y E A R+\varepsilon_{2}
\end{gathered}
$$

The figure contained in the Appendix shows, using a blue border, the location of Meriwether County. Also highlighted there (with a black border) are the counties contiguous to Meriwether, where Roosevelt either travelled between 1924 and 1945, or from where Georgia citizens travelled to Warm Springs (in Meriwether County) to see Roosevelt. These counties in west-central Georgia include Coweta, Harris, Pike, Spalding, Upson, Talbot and Troup. (Note 15) Also included in the map are markers for the various historical spots included in the brief history in the previous section of this study. Support for the friends-and-neighbors (localism) voting hypothesis discussed here and in previous studies would be exhibited by a positive sign on both $\beta_{1}$ from equation (2) and $\delta_{1}$ from equation (3), respectively.

Both equations also include the dummy variable LGCAP, which is equal to 1 for the counties containing Georgia's largest city and its capital city, which is Atlanta in both cases, and 0 otherwise. As indicated above, Georgia Governor Eurith Rivers visited Roosevelt in Warm Springs during 1938. Rivers, who served as Governor from 1937 to 1941, was a Democrat who staunchly supported Roosevelt's New Deal policies. As such, he would have worked to promote Roosevelt's candidacy in 1940, and that support would be exhibited in the county precincts surrounding Georgia's capital and largest city, Atlanta. The same would have been true in 1944, when liberal Democrat Ellis Arnell was Governor of Georgia. Thus, it is expected that LGCAP will be positively related to VOTESHARE in equations (2) and (3). The additional variable in the panel data test, YEAR, is a variable equal to 1 for the countywide results from the 1940 presidential election, and 2 for those from the 1944 presidential election. It is included to capture any difference in Georgia voter sentiment toward Roosevelt between the 1940 and 1944 elections. As such, the relationship between YEAR and VOTESHARE is treated as an empirical question.

Results from two separate OLS estimations of equation (2) above - one for the 1940 presidential election and another for the 1944 presidential election - are shown in columns two and three of Table 1. In both cases, HOME is positively signed and statistically significant at the 0.05 level or better. In fact, tests indicate that the friends-and-neighbors voting effect favoring Roosevelt in the west central Georgia election returns of 1940 was a solid 5.6 percentage points. This figure is quite comparable to those found in Lewis-Beck and Rice (1983), Mixon and Tyrone (2004) and Mixon, King and Lawing (2009), which range from four percentage points to 5.5 percentage points. The second test, that for the 1944 Georgia returns, indicates that the friends-and-neighbors voting effect favoring Roosevelt was a robust 9.9 percentage points, or about 1.8 times larger than that from the 1940 U.S. presidential election. Still, this figure (i.e., 9.9 percentage points) fits quite nicely in the home-county effect range of 8.18-12.35 percentage points found in Kjar and Laband (2002). Lastly, LGCAP fails to reach an acceptable significance level in either of the first two sets of results, thus failing to support the gubernatorial support hypothesis stated above. 
Table 1. OLS Results for Georgia's General Elections (Dep Var = VOTESHARE)

\begin{tabular}{ccccc}
\hline Variables & 1940 only & 1944 only & $1940 \& 1944$ & $1940 \& 1944$ \\
\hline Constant & $86.005^{*}$ & $81.686^{*}$ & $83.846^{*}$ & $89.968^{*}$ \\
& $(0.734)$ & $(0.8)$ & $(0.554)$ & $(1.67)$ \\
& & & & \\
HOME & $5.645 \dagger$ & $9.914^{*}$ & $7.779^{*}$ & $7.779^{*}$ \\
{$[0.050,0.219]$} & $(3.263)$ & $(3.556)$ & $(2.462)$ & $(2.409)$ \\
LGCAP & -2.405 & 1.214 & -0.596 & -0.596 \\
{$[0.006,0.079]$} & $(9.023)$ & $(9.833)$ & $(6.807)$ & $(6.66)$ \\
YEAR & & & & $-4.082^{*}$ \\
{$[1.500,0.501]$} & & & & $(1.053)$ \\
$n$ & 159 & 159 & 318 & 318 \\
$R^{2}$ & 0.019 & 0.048 & 0.031 & 0.075 \\
\hline
\end{tabular}

Notes: The numbers in parentheses are standard errors. ${ }^{*}(\dagger)$ denotes $.01(.05)$ level of significance or better for a one-tailed test. The numbers in brackets are means and standard deviations for the pooled (panel) data.

The final two columns of Table 1 report results from the panel data estimates. There, HOME is again positively and statistically significantly related (at the 0.01 level) to VOTESHARE. When both the 1940 and 1944 election results are combined, the home-area effect favoring Roosevelt is a solid 7.8 percentage points, a figure that lies just below the lower-bound estimate found in Kjar and Laband (2002). In the panel data estimation, the negative and statistically significant estimate for YEAR suggests that statewide support (in Georgia) for Roosevelt eroded by about 4.1 percentage points between the 1940 and 1944 U.S. presidential elections. The general drop in support for Roosevelt likely reflects growing wartime fatigue among the Georgia electorate between the autumn of 1940, or about 12 months before the Japanese bombing of Pearl Harbor, and the fall of 1944, or about five months after the allied invasion of Normandy. This erosion occurred, however, when support for Roosevelt in Meriwether and contiguous counties grew. In fact, the growth in friends-and-neighbors electoral support of about 4.2 percentage points exceeded slightly the general statewide erosion of support occurring from 1940 to 1944 . This finding, which is quite remarkable, offers compelling support for the friends-and-neighbors voting hypothesis tested here and in previous studies.

For comparison with the 1940, 1944 and 1940-1944 results for Georgia described above, equations (2) and (3) were re-estimated using data from New York, Roosevelt's home state. As mentioned in the introduction, Roosevelt's younger years were spent in Hyde Park, New York, which is located in Duchess County. Surrounding Duchess County in New York are Columbia County, Orange County, Putnam County and Ulster County. In this case, HOME is a dummy variable equal to 1 for observations involving these five counties, and 0 otherwise. Also, the Governor of New York at the time of the 1940 election was Herbert Lehman, a Democrat who, like the governors in Georgia, supported Roosevelt's New Deal policies. Lehman's influence extends to New York City as well, given that he was one of the partners of the well-known financial services firm Lehman Brothers. This influence may have even mitigated some of the expected negative effects from having Roosevelt's Republican rival Thomas Dewey serving as New York Governor at the time of the 1944 presidential election. Thus, LGCAP, which is a dummy variable equal to one for counties containing New York City and New York's capital, Albany, and 0 otherwise. Lastly, the variable YEAR is included in the models employing panel data, in order to capture any change in voter sentiment toward Roosevelt between the 1940 and 1944 elections.

Results from two separate OLS estimations, each using county-level general elections data from New York, of equation (2) above - one for the 1940 presidential election and another for the 1944 presidential election - are shown in columns two and three of Table 2. In neither case is HOME both positively related to VOTESHARE and statistically significant (at the 0.05 level or better). In the one case wherein HOME is positively signed, its estimate is only about 65 percent as large as its counterpart from the models above employing general elections 
shares from Georgia. In this case (i.e., 1940 only), however, the parameter estimate for HOME (i.e., 3.7) is significant at only the 0.12 level. It is interesting that in the OLS models for New York, LGCAP is both positively signed and statistically significant. In fact, Roosevelt's support in Albany and New York City exceeded that in the other counties, ceteris paribus, by 17.2 percentage points in 1940, and by 8.2 percentage points in 1944. The decrease from 17.2 percentage points to 8.2 percentage points is also consistent with the gubernatorial turnover that occurred between these two elections years. In 1940, New York was led by Lehman (D-NY), while Dewey (R-NY) held gubernatorial office in 1944. Unlike the case of Georgia, LGCAP provides some support for the gubernatorial support hypothesis when the models are applied to New York.

Table 2. OLS Results for New York's General Elections (Dep Var = VOTESHARE)

\begin{tabular}{lllll}
\hline Variables & 1940 only & 1944 only & $1940 \& 1944$ & $1940 \& 1944$ \\
\hline Constant & $33.896^{*}$ & $34.013^{*}$ & $33.955^{*}$ & $35.501^{*}$ \\
& $(0.931)$ & $(0.869)$ & $(0.644)$ & $(1.884)$ \\
HOME & 3.684 & -0.273 & 1.705 & 1.705 \\
{$[0.081,0.273]$} & $(3.143)$ & $(2.934)$ & $(2.173)$ & $(2.176)$ \\
$L G C A P$ & $17.204^{*}$ & $8.167^{*}$ & $12.685^{*}$ & $12.685^{*}$ \\
{$[0.081,0.273]$} & $(3.143)$ & $(2.934)$ & $(2.173)$ & $(2.176)$ \\
YEAR & & & & -0.931 \\
{$[1.500,0.502]$} & & & & $(1.181)$ \\
$n$ & 62 & 62 & 124 & 124 \\
$R^{2}$ & 0.34 & 0.118 & 0.22 & 0.224 \\
\hline
\end{tabular}

Notes: The numbers in parentheses are standard errors. ${ }^{*}(\dagger)$ denotes $.01(.05)$ level of significance or better for a one-tailed test. The numbers in brackets are means and standard deviations for the pooled (panel) data.

The final two columns of Table 2 report results from the panel data estimates. There, HOME is positively related to VOTESHARE, however its parameter estimate of 1.7 is not statistically significant. Also in the panel data estimation, the negative estimate for YEAR suggests that statewide support (in New York) for Roosevelt eroded by about one percentage point between the 1940 and 1944 U.S. presidential elections. As with HOME, however, this estimate is not statistically significant. The only hypothesis that is supported using presidential election returns from New York's counties is the gubernatorial support hypothesis. In the panel data estimations, LGCAP is positive and statistically significant, indicating greater support for Roosevelt in and around Albany and New York City, ceteris paribus. Taken together, the results indicate greater support for friends and neighbors voting regarding Roosevelt's visits to Warm Springs, Georgia, than that found for his younger years in Hyde Park, New York.

\section{Concluding Comments}

The present study extends recent research on friends-and-neighbors voting in U.S. presidential elections by examining President Franklin D. Roosevelt's victories in both the 1940 and 1944 presidential elections, victories that secured for Roosevelt a third and fourth presidential term, respectively. What makes these elections a potentially rich source of information about friends-and-neighbors voting is that Roosevelt, who grew up in Hyde Park, New York, spent a large portion of his life in Warm Springs, Georgia, receiving hydrotherapy for problems associated with polio, a disease he contracted in the early 1920s. By the 1940s, Roosevelt's visits to west central Georgia led many rural Georgians - farmers, merchants and others who lived in and around Meriwether County - to consider the U.S. President to be their friend and advocate. Indeed, the empirical results presented in this study indicate that the localism or friends-and-neighbors voting effect favoring Roosevelt in Meriwether and contiguous Georgia counties averaged a robust 7.8 percentage points across the presidential elections of 1940 and 1944. This result is even more striking when compared to the smaller home-area effect found for Roosevelt from the Duchess County area of New York, which includes his boyhood home in Hyde Park. In some ways, the findings discussed in this study offer even more compelling support for the friends-and-neighbors voting hypothesis from public choice economics than do previous studies of voting in presidential elections in the United States. Finally, future research on friends-and-neighbors voting could 
concentrate more on the secondary home aspect of presidential elections highlighted in this study, perhaps even delving into differences between pre- and post-elective office living circumstances.

\section{Acknowledgements}

The author thanks two anonymous referees of this journal and participants in a CSU organizational leadership seminar for several helpful comments on an earlier version, and officials with the University System of Georgia for compiling some of the history cited in this study. The usual caveat applies.

\section{References}

Aspin, L. T., \& Hall, W. K. (1989). Friends and Neighbors Voting in Judicial Retention Elections: A Research Note Comparing Trial and Appellate Court Elections. Political Research Quarterly, 42, 587-596. http://dx.doi.org/ 10.1177/106591298904200409

Devine, C. J., \& Kopko, K. C. (2011). The Vice Presidential Home State Advantage Reconsidered: Analyzing the Interactive Effect of Home State Population and Political Experience, 1884-2008. Presidential Studies Quarterly, 41, 1-17. http://dx.doi.org/ 10.1111/j.1741-5705.2010.03828.x

Disarro, B., Barber, J., \& Rice, T. W. (2007). The Home State Effect in Presidential Elections: Advances in the $\begin{array}{lllll}\text { Study of Localism. Presidential Studies } & \text { Quarterly, 37, 558-566. }\end{array}$ http://dx.doi.org/10.1111/j.1741-5705.2007.02612.x

Editors. (2009). Franklin D. Roosevelt in Georgia. The New Georgia Encyclopedia. Retrieved September 21, 2012, from http://www.georgiaencyclopedia.org/nge/Article.jsp?id=h-2727

Editor. (1924, October 26). Franklin Roosevelt Will Swim to Health. Atlanta Journal Sunday Magazine, 7.

Faith, R. L., \& Tollison, R. D. (1983). Voter Search for Efficient Representation. Research in Law and Economics, 5, 211-224.

Gallagher, H. G. (1994). FDR's Splendid Deception: The Moving Story of Roosevelt's Massive Disability and the Intense Efforts to Conceal it from the Public. Arlington, VA: Vandamere Press.

Gimpel, J. G., Karnes, K. A., McTague, J., \& Pearson-Merkowitz, S. (2008). Distance-Decay in the Political Geography of Friends-and-Neighbors Voting. Political Geography, 27, 231-252. http://dx.doi.org/ 10.1016/j.polgeo.2007.10.005

Hudson, P. S. (1994). A Call for 'Bold Persistent Experimentation': FDR's Olgethorpe University Commencement Address, 1932. Georgia Historical Quarterly, 78, 361-375.

Kahane, L. H. (2009). It's the Economy, and then Some: Modeling the Presidential Vote with State Panel Data. Public Choice, 139, 343-356. http://dx.doi.org / 10.1007/s11127-009-9397-z

Kjar, S. A., \& Laband, D. N. (2002). On 'Home Grown-ness' in Politics: Evidence from the 1998 Election for Alabama's Third Congressional District. Public Choice, 112, 143-150. http://dx.doi.org/10.1023/A\%3A1015605301245

Klein, B., \& Leffler, K. B. (1981). The Role of Market Forces in Assuring Contractual Performance. Journal of Political Economy, 89, 615-641.

Lewis-Beck, M. S., \& Rice, T. W. (1983). Localism in Presidential Elections: The Home State Advantage. American Journal of Political Science, 27, 548-556.

Lippman, T. Jr. (1977). The Squire of Warm Springs: F.D.R. in Georgia, 1924-1945. Chicago, IL: Playboy

Malcbress ${ }_{K}$. (2012). The Local Aspect of Electoral Support for Candidates to the Senate of the Czech Republic. Czech Sociological Review, 48, 283-313.

Mixon, F. G. Jr., King, E. W., \& Lawing, M. L. (2008). Modeling the Impact of Localism in U.S. Presidential Elections. Journal of Public Finance and Public Choice, 26, 3-18.

Mixon, F. G. Jr., \& Tyrone, J. M. (2004). The 'Home Grown' Presidency: Empirical Evidence on Localism in Presidential Voting, 1972-2000. Applied Economics, 36, 1,745-1,749. http://dx.doi.org/10.1080/0003684042000227886

NPS [National Park Service]. (2012). Roosevelt's Little White House. Retrieved September 21, 2012, from http://www.nps.gov/nr/travel/presidents/roosevelts_little_white_house.html.

Roosevelt, E. (1950). F.D.R.: His Personal Letters, 1905-1928. New York, NY: Duell, Sloan and Pearce. 
Sass, T. R. (1992). Constitutional Choice in Representative Democracies. Public Choice, 74, 405-424. http://dx.doi.org /10.1007/BF00137687

Stevens, R. (1947). Hi-Ya Neighbor: Intimate Glimpses of Franklin D. Roosevelt at Warm Springs, Georgia 1924-45. Atlanta, GA: Turner and Love.

U.S. Bureau of the Census. (1946). Vote Cast in Presidential and Congressional Elections, 1928-1944. Retrieved from http://books.google.com/books?id=R1Q_AAAAYAAJ\&printsec=frontcover\&source=gbs_ge_summary_r $\& \mathrm{cad}=0 \# \mathrm{v}=$ onepage $\& \mathrm{q} \& \mathrm{f}=$ false

University System of Georgia (USG). (2012). Franklin D. Roosevelt's visits to Georgia. Retrieved September 21, 2012, from http://georgiainfo.galileo.usg.edu/FDRvisit.htm.

Winn, W. W. (1996). The view from Dowdell's Knob. New Georgia Guide (pp. 359-389). Athens, GA: University of Georgia Press.

\section{Notes}

Note 1. See Sass (1992) for an excellent overview, within a constitutional choice framework, of the decision-making and agency costs of representative democracy.

Note 2. Lewis-Beck and Rice's (1983) analysis of equation (1) yielded 42 observations.

Note 3. Kahane (2009) regresses the incumbent party candidate's vote share, while Mixon and Tyrone (2004) and Mixon, King and Lawing (2008) regress the winning candidate's vote share. Mixon, King and Lawing (2008) argue that omission of economic variables from the latter specification is not problematic.

Note 4. The individual credited with benefitting from bathing in the warm springs of Meriwether County is Louis Joseph, a New Yorker who had once lived in Columbus, Georgia, which is only 40 miles from Warm Springs. Former newspaper publisher Tom Loyless described Joseph's recovery to Peabody, who then relayed the story to Roosevelt, prompting Roosevelt's first visit to the Meriwether Inn and its grounds (Editor, 1924; NPS, 2012; USG, 2012).

Note 5. Roosevelt would often remain in the waters for two hours or more (Editor, 1924; USG, 2012).

Note 6. Many of the new visitors who suffered from polio began referring to Roosevelt as "Dr." (Lippman, 1977; USG, 2012).

Note 7. Historians also point out that Roosevelt used his time in west-central Georgia to develop visual tricks, such as leaning against cars or walking with his arm on the elbow of someone else, in order to appear more physically fit to the general public (Gallagher, 1994; Editors, 2009). These habits likely assisted him in his bid for the presidency, given public attitudes toward disabilities in leaders at that time.

Note 8. The name, "The Little White House," was coined by Arthur Carpenter, an official with the Georgia Warm Springs Foundation, Inc., in May of 1932, several months before Roosevelt was elected president (USG, 2012).

Note 9. Roosevelt's correspondence indicates that he was thinking about the effects on Georgians of the Great Depression well before he assumed the presidency in 1933. In a letter from October of 1930, Roosevelt invited the Governor of Florida, Doyle Carlton, and the Governor-Elect of Georgia, Richard Russell, to join him in Warm Springs in order to discuss "Georgia's tax problem" (Roosevelt, 1950; USG, 2012). Later, at the beginning of his career as a U.S. Senator, Russell supported President Roosevelt's New Deal policies (USG, 2012).

Note 10. Roosevelt's adoption of Georgia as his second home did not always involve travel around the state. During the spring of 1925, he was hired by Tom Loyless, the editor of The Macon Telegraph, to write nine editorial columns for the newspaper (USG, 2012). Macon, Georgia, home to The Macon Telegraph, is located in Bibb County, three counties to the southeast of Meriwether County.

Note 11. It was during Roosevelt's 11 August 1938 trip to Athens, in the eastern Georgia hills, to deliver the commencement address at the University of Georgia, that he spoke of how his experiences in west central Georgia framed his development of various New Deal ideas. It was then that he also spoke about the poverty that remained in Georgia, and how his "Hours and Wages" bill would alleviate it to some degree (Lippman, 1977; USG, 2012). 
Note 12. Roosevelt visited Columbus and Fort Benning on 30 March 1938. Hosted by Georgia Governor Eurith Rivers, Roosevelt was greeted by a crowd of 50,000 people along the streets of Columbus (USG, 2012). Roosevelt, accompanied by Georgia Governor Ellis Arnall, made another such visit to Columbus and Fort Benning during his 15 April 1943 through 17 April 1943 trip to Warm Springs. During this visit, he attended several officer training classes and viewed some tactical maneuvers (USG, 2012). Throughout the period during which Roosevelt visited west-central Georgia, Columbus' main newspaper, The Columbus Ledger, often kept area citizens apprised of his comings and goings (USG, 2012).

Note 13. Dowdell's Knob is just to the southwest of Roosevelt's home near Warm Springs, and offers views of areas in northeast Harris County, near Pine Mountain, Georgia, that are now part of Franklin Roosevelt State Park. Harris County, just to the south of Meriwether County, was also frequented by Roosevelt.

Note 14. The data used in this study come from Votes Cast in Presidential and Congressional Elections, 1928-1944, published by the U.S. Bureau of the Census (1946).

Note 15. Cities and towns in these counties include Newnan (Coweta), Hamilton (Harris), West Point (Harris and Troup), Griffin (Spalding), Thomaston (Upson), Talbotton (Talbot), Manchester (Talbot) and LaGrange (Troup). 


\section{Appendix}

Map of Georgia (Counties)

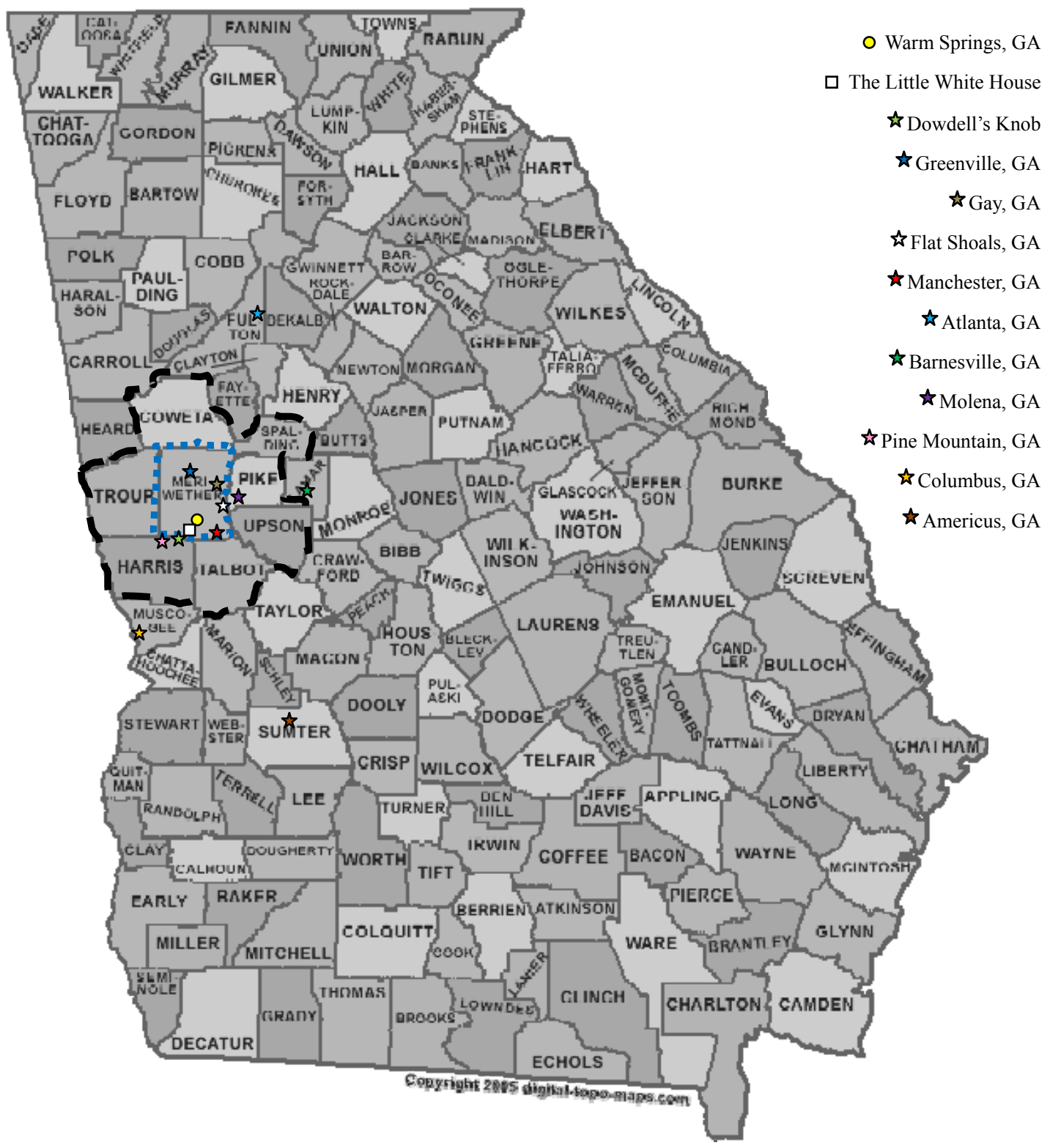

Source: Google Images

\section{Copyrights}

Copyright for this article is retained by the author(s), with first publication rights granted to the journal.

This is an open-access article distributed under the terms and conditions of the Creative Commons Attribution license (http://creativecommons.org/licenses/by/3.0/). 